\title{
Differences in Activities, Teacher Questioning, Teacher Modelling and High Level Thinking Skill Based on Races in Kudat, Sabah
}

\section{Tajul Rosli Bin Shuib, Mohd Razimi Husin, Nor Hasnida Che Md Ghazali}

To Link this Article: http://dx.doi.org/10.6007/IJARBSS/v9-i7/6788

DOI:10.6007/IJARBSS/v9-i7/6788

Received: 22 May 2019, Revised: 15 June 2019, Accepted: 29 June 2019

Published Online: 09 July 2019

In-Text Citation: (Shuib et al., 2019)

To Cite this Article: Shuib, T. R. Bin, Husin, M. R., \& Ghazali, N. H. C. M. (2019). Differences in Activities, Teacher Questioning, Teacher Modelling and High Level Thinking Skill Based on Races in Kudat, Sabah. International Journal of Academic Research in Business and Social Sciences, 9(7), 1404-1417.

Copyright: (c) 2019 The Author(s)

Published by Human Resource Management Academic Research Society (www.hrmars.com)

This article is published under the Creative Commons Attribution (CC BY 4.0) license. Anyone may reproduce, distribute, translate and create derivative works of this article (for both commercial and non-commercial purposes), subject to full attribution to the original publication and authors. The full terms of this license may be seen

at: http://creativecommons.org/licences/by/4.0/legalcode

Vol. 9, No. 7, 2019, Pg. 1404 - 1417

Full Terms \& Conditions of access and use can be found at http://hrmars.com/index.php/pages/detail/publication-ethics 


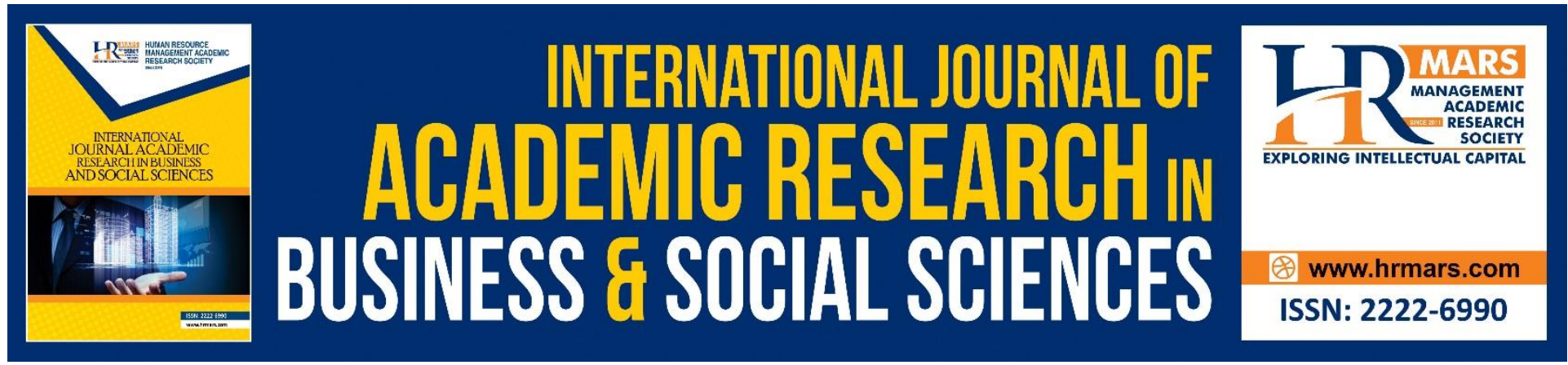

\title{
Differences in Activities, Teacher Questioning, Teacher Modelling and High Level Thinking Skill Based on Races in Kudat, Sabah
}

\author{
Tajul Rosli Bin Shuib \\ SMK Sungai Manik, Perak. \\ Email: tajul_roslie@yahoo.com
}

\author{
Mohd Razimi Husin, Ph.D, Nor Hasnida Che Md Ghazali, Ph.D \\ Universiti Pendidikan Sultan Idris \\ Email: Razimi@Fpm.Upsi.Edu.My, hasnida@fpm.upsi.edu.my
}

\begin{abstract}
The purpose of this study was to identify whether or not there are significant differences in the variables of student centralization, teacher questioning, teacher modelling and high level thinking skill of students based on the race of primary school students in Kudat, Sabah, Malaysia. This quantitative study used a survey method involving 250 respondents from the stated population. This study referred to the Absorption Learning Model (Swartz, Fischer and Parks, 1998) as its basis. Data analysis was done using one way ANOVA analysis with Statistical Package for Social Science (SPSS) version 22. Based on the students in Kudat district, the results showed that Dusun students as Islamic minorities were mostly interested in the questionnaire and modelling of teachers in the class. In addition, all students from every ethnic group have the same tendency towards the continuity of socialisation from outside the classroom such as student centring activities and high-level thinking skills for Islamic Education subjects. It is hoped that this study will provide useful inputs for improving teachers' infusion teaching practices on racial diversity and religious background in Kudat and other regions.
\end{abstract}

Keywords: High Level Thinking Skill, Low-Performing Schools, Activities, Questioning, Modelling

\section{Introduction}

Based on the Islamic Education Philosophy (FPI), students are raised to become believing Muslim individuals through the learning environment at school. However, FPI does not rule out the need for soft skills so that students can compete in the working market either professional, partial professional or practical (Rahim, 2001) after graduation. To achieve this, students need a set of quality thinking skills that include emotional intelligence, self- 
management, problem solving, creativity and others (Rajendran, 2013). Recognising this importance, the authorities through the Ministry of Education Malaysia (MOE) took the initiative to empower thinking skills in the school curriculum since the early 90 s with infusion learning through the Primary/Secondary School Integrated Curriculum (KBSR/M) that implements Creative and Critical Thinking Skills (KBKK) across the curriculum. The continuous improvement of the parties continued with the Secondary School Standard Curriculum (KSSM) with a greater emphasis on High Level Thinking Skills (KBAT) and continuous student assessment in the classroom that reduced the exam-oriented sentiment (Curriculum Development Section, 2016).

Since KBSR/M has begun, curriculum and teaching specialists from within and outside the country have been used to provide teacher-oriented approaches, strategies, methods and techniques for implementing the infusion (Rajendran, 2013). In terms of implementation, teachers face challenges to vary each approach to meet the needs of the current education and touch on the cognitive, affective and psychomotor aspects of the students (Audrey, 2010). Various forms of activities that promote cooperation, leadership and speech (Mel, 2010) are recommended for teachers and students' practice as a learning strategy. While the student centering strategy is better to encourage thinking skills, conventional teaching strategies are more frequently used by teachers (Rajendran, 2013; Azmi \& Halim, 2007) as they are easier in terms of time and class control. However, this study did not reject strategies such as chalk and talk since they are very important in the teaching of most of the Islamic Education syllabus with in depth discussion including deep learning (Marton \& Saljo, 2005). Teachers' in depth debate requires strengthening to set the focus and test the understanding of students. In that case, the teachers should perform questionnaires and some simple activities to create a more constructive interactive class (Tamuri et al., 2004) with the correct discipline. The two-way interaction promotes openness in out-of-box and contextual discussions (Fisher, 2009) and philosophies (Rosnani, 2012). To further empower the use of conventional strategies, Brookfield (2005) emphasised the importance of 'neglected pedagogy' - teacher modeling - in the teaching of curriculum infusion and thinking skills. Practically, the systematic nature of the three variables is to adhere to the concept of an active learning atmosphere or at least partially active and in line with some groups of student who are still having high dependency on teachers. The effectiveness of transformational empowerment is able to gradually shape the students to be more constructive.

Ubian, Kegayan, Bajau, Dusun and some other minorities are among the races living in Kudat. In terms of socio-economic system, most students here are from low and middle income families. According to Kanazawa (2010), societies living in the majority-of-life groups are happier, more comfortable and smarter than the communities in the minorities. If this is true, then poor students in the population of this study do not have problems in learning as they are the majority group. They have high motivation and equal opportunity to advance in terms of learning. All students in the population of this study go to government schools with moderate mean score achievements. Teachers are particularly committed in providing the best education to the students and to make them useful to the family, thus serving the religion as a da'i at least in small groups.

\section{Statement of Problem}

Students in Malaysia are found to be quite uncomfortable to discuss matters related to Islam (Nur, 2016). They take the easy way by responding "do not know" to any religious questions. 
This explains that the in depth cultural discussion and expressing opinions in harmony are not yet existed among the students. These can be corrected by in depth learning culture during teaching and learning through various approaches. The norms in teaching among teachers who love to use conventional approaches - although doubtful - are actually still relevant, but student activities and teacher questioning need to be evaluated and re-empowered by the implementation of a structured model in line with the needs of the learning in the 21st century. Attention should be given to rural students based on the socio-economic system of moderate and low-income families in

the majority.

Suhaimi (2014) found that rural students still rely on teacher guidance more than the dependency of urban students. This indicates that the concentration of students among rural students should be nurtured despite their time constraints, controls and engagement. Students should be taken out from the "comfortable" learning environment and should be encouraged not to learn constructively. In the case of teacher questioning in class, Rajendran (2013) discovered that there are still less skilled teachers with the correct questioning techniques in the classroom. The study was supported by Seman (2005) and Waheedawati (2003), which found that teachers are only required to give cognitive questions in the low or medium level with the two-way interaction that did not work well while questioning is the most important element in sharpening thinking skills. In-depth learning can only be implemented with an effective questionnaire (dialogue). In addition, Brookfields (2015) claimed that teachers often ignore the modelling while implementing curriculum inflections and thinking skills in the classroom. Teachers often teach and expose students with a variety of techniques to answer high-level questions. Thinking tools are also used in the classroom with teachers that rarely show a high level of arranged argument as expert thinkers (Rajendran, 2013).

To implement interesting learning, Ellen (2014) found that teachers are given with student constraints in terms of ability, confidence, acceptance, time and class control. At the same time, they are also handed with many tasks with less time thinking of any innovation in the classroom. In addition, low and medium achievement students did not provide encouraging participation in over-constructive learning strategies (Howard \& Nancy, 2006). As a result, some teachers chose to return to the old method without appropriate transformation. As an effort to encourage the building of knowledge of the less 'friendly-constructive' students, the teacher should at least naturally make a partial active learning and give benefit through highlevel inquiry and dialogue of students even in a small group.

Most Dusun students have relatives who are non-Muslims and practice their ancestral beliefs (Hanafi, 2012). Compared to other students, Dusun students are minorities in the Islamic groups. Non-Islamic environment in terms of belief, worship, social and nutrition can cause confusion and insensitivity to the true teachings of Islam. Hence, learning in the classroom is very meaningful for students. From the perspective of socio-economic system, Tamuri, Mahmud and Bari (2005) found that students in lower socio-economic system are exposed to disciplinary problems and less academic. The phenomenon in population of this study was in line with the allegations (Ab. Halim, 2005) as nine of the 11 secondary schools in Kudat district are at the lowest band level according to current academic achievement. From the aspect of thinking skills among rural learners, Goleman (2006) found that students are exposed to 
fallacious reasoning, which was the influence of the environment that dampened the openness of students' thinking. Besides, Rohani and Nordin (2010) proved that family economic background does not significantly affect students' commitment. This scenario illustrates various possibilities that can occur in rural communities and can only be controlled through a planned educational system.

Overall, although Kanazawa (2010) proved that people in the majority are comfortable, happy and smart, Ainon and Abdullah (2005) found that there was no connection between intelligence and students' thinking skills. It can be concluded that every student regardless of race and socio-economic potential has the ability to generally have high-level thinking skills and to appreciate, practice and convey the teachings of Islam in particular. Based on the needs of the current teaching phenomenon with the needs of the 21st century learning, the study on the element of teaching and learning through student-centring activities, teacher questioning and teacher modelling among rural students should be studied so that any improvement can be discussed based on the differences between students and help to raise the level of students' thinking skills to the best level.

\section{Literature Highlights}

The Ministry of Education has long started its action to work on high-level thinking skills among students in Malaysia since the 90s (Rajendran, 2013). This begins with the application of creative thinking and critical thinking skills (Rajendran, 2013) through the Secondary School Integrated Curriculum (KBSM) until high-level thinking skills (KBAT) through the Secondary School Standard Curriculum (KSSM). The efforts to introduce the best teaching strategy as well as thinking tools designed by local and foreign experts are still actively pursued by the ministry (Rajendran, 2013). To date, the stalemaking efforts are still ongoing with the adoption of KBAT as an important element in the primary and secondary school assessments with the re-branding of KBSM to KSSM along with various improvements in the assessment with the intention of empowering students' thinking in tandem with the 21st century learning challenges (Curriculum Development Section, 2016). In the context of new curriculum, the Ministry of Education strives to reduce the dependency on exam-orientation and empowering teachers' profession through assessment by form and assessment of Form Three as a measure of achievement for knowledge, practicality, practice, appreciation and consistency (istiqamah). To celebrate the package to reduce the exam and to override KSSM's assessment, the form and course of the teaching of teachers had returned as the focus.

In general, there are two strategies in teaching that can be used; teacher centering teaching and student centering teaching. Csete and Gentry (in Noor, 2011) stated that the centralization of teachers is the only primary source of knowledge transfer while student centering learning is a self-controlled learning process. The extent to which the centralization of students can be implemented among weak students is yet to be studied. To address the difficulty of carrying out student centering activities, some efforts done to highlight student centering activity modules (Jonathan, 2011; Mel, 2010) are fascinating and full of discipline, speed and timing and encourage students to argue, stretch, interact, solve problems, evaluating, criticizing, acting and exchanging opinions. Trained Islamic Teachers can adapt these modules to the contents of the Islamic Education curriculum so as to achieve the main objectives of the subject, which is the appreciation that leads to the lifestyle of students inside 
and outside the school. Although active learning activities are difficult to implement in some groups of student, individual learning alone does not help the students to achieve psychomotor capabilities. Hence, at least there is a teacher's effort to guide students towards active or partial learning with appropriate approaches.

Questioning is a compulsory and commonly used tool for teachers in the classroom (Robert, 2009) to promote focus, test and sharpen students' thinking. Issues that dispute not only the extent to which teachers' quizzes are effective in achieving the syllabus's objectives, but whether or not they bring students to an in depth discussion dialogically. Some types of questions and levels of questioning can be used in questionnaire with students (Rosnaini et al., 2011). Additionally, the Bloom's taxonomy (in Krathwohl \& Anderson, 2009) is so synonymous with questionnaires based on the level of testing the students' knowledge to the students' skills in assessment and synthesis. Teachers should be able to mix the divergent and convergent questions with their levels and other thinking tools. Socrates (in Braun et al., 2015) makes questioning as the primary element of his teaching. Nonetheless, the technique of the Socratic questionnaires does not just focus on the questions of a certain level, but also systematic, organized and critical (Braun et al., 2015; Richard \& Linda, 2006). Even in the world of advanced education with sophisticated teaching-learning technology, the success of a lesson depends on the teachers' ability in questioning.

A teaching tool that is often marginalized by a teacher when implementing the teaching infusion is modelling. In a new era that emphasizes thinking skills beyond knowledge, conventional approaches such as lectures and descriptions alone make learning process to become crippled. Guidance "by exemplar" should be cultivated among teachers. Modelling has become one of the most challenging strategies for teachers since there is a basic protocol that must be mastered prior to starting each teaching session such as techniques of thinking teaching and culture analysis to critically analyses teachers' personal daily experience (Brookfield, 2015; Bryan, 2009; Bob \& Peter, 2009). Only Islamic Education teachers who make thinking as a daily practice can become expert thinkers in the students' view because modelling for thinking in high level is not just acting and scripting, but natural and dynamic towards planned and unplanned discussions. Teachers who do not master the basis of modelling in debating with thinking skills will abandon the question and make education of thinking as a rigid and non-original learning. Like student centralization and teacher questioning, the modelling also needs to be worked together with thought-provoking tools to be diverse and learning to be interesting for the students to continue engaging and becoming individuals who practice the thinking activity.

\section{Research Objective}

The objective of this study is to identify whether or not there is a significant mean difference in the variables of student centralization, teacher questioning, teacher modelling and high level thinking skills based on the aspect of race.

\section{Study Hypotheses}

$\mathrm{H} \_01$ : There is no significant difference in mean score of student-centering activity variable based on race. 
H_02: There is no significant difference in mean score of teacher questioning variable based on race.

H_03: There is no significant difference in mean score of teacher modeling variable based on race.

H_04: There is no significant difference in mean score of KBAT variable based on race.

\section{Operational Definitions}

\section{Student Centering Activity}

The student centering activity refers to the activities in the group organized by the teacher to be carried out by students in the learning process to achieve learning objectives. It provides space for students to determine objectives, assignments and learning resources (Noor, 2011). Among other terms used for this purpose are self-directed learning, group learning, peer-topeer teaching and student-based learning. For this study, the same definition was used by making constructivist cognitive theory as a specific reference. This study did not focus on constructivist cognitive collaboratively since previous studies (Suhaimi, 2014; Tamuri et. al., 2004; Rosnani, 2003) stating that dependency of rural students was still high on teachers and not group learning. Whether or not the teachers apply them comprehensively, this study examines the differences in student centering activities based on the race of students through questionnaires adapted from previous questionnaires and expert teachers' views.

\section{Teacher Questioning}

Questioning is the activity of the teachers to get the response from the students whether or not they understand the topics delivered (Kamarul \& Ab Halim, 2007). Various questions and levels of questionnaire have been highlighted by various parties to create a teaching and learning environment that develops student minds as well as strengthening their knowledge in the lesson. Questioning by Bloom's taxonomy (in Krathwohl \& Anderson, 2009) is a commonly used questionnaire and practice in classroom and training. For this study, the approximate definition was also applied. To adapt thinking skills in Islamic Education, not just the level of questioning that should be considered, but also teachers' creativity in asking a good and challenging question in accordance with Bloom's taxonomy as well as the criteria proposed by Edward (2000) to develop a dialogic interaction that leads to appreciation and practice.

\section{Teacher Modelling}

Modelling is a learning by exemplar including demonstration. Meanwhile, demonstration is done to show students on how to perform specific tasks accompanied by oral descriptions (Tegin et al., 2009). Usually, a student or teacher shows a method that can be understood to do some movement, procedure or means using an object. If it is worthwhile to find discovery and deprivation, it is called an experiment. In the study of high-level thinking skills, modelling is focused on how the teacher as a role model describes the teaching content using structured and critical thinking techniques. Bandura (in Rosnaini et al., 2011) pioneered social cognitive theories in which he suggests that learning takes place through a modelling process of observation and impersonation that also involved cognitive processes. Students will not think very well with the instruction of the teacher alone unless it is normal to observe the situation by observing the teacher that continuously debates as an expert thinker (Edward, 2015; Rajendran 2013; Stephen, 2013; Brookfields, 2012). 


\section{High Level Thinking Skills (KBAT)}

KBAT is the ability of students to apply knowledge, skills and values in making reasoning and reflection to solve problems, make innovative decisions and be able to create something (Curriculum Development Section, 2016). KBAT's goal is to produce students who no longer rely on mere memorization (Rosnani et al, 2014) in understanding the subject matter and expanding their thinking to a better level and in line with the current modernization trend. KBAT in Islamic Education is a quest for searching the value behind something (Rosnani, 2014) by linking and discussing to understand Islamic teachings better. Rosnani (2014) emphasized that philosophy is necessary in educating students to be more critical. Thus, the skill of questioning and explanation and activity formation is very important to be examined with the existing teacher's expertise.

\section{Low-performing Schools}

The lower-performing schools are not officially mentioned in any circular of the Ministry of Education. However, every school in Malaysia is subjected to the banking system implemented by the ministry. The positions of the schools are determined by the band starting from Band 1 as best to Band 7 as the weakest. Following the banking system, the ministry introduced two new posts through the Malaysian Education Development Plan 20132025, which are School Improvement Specialist Coach Plus (SISC+) and School Improvement Partner (SIP) to guide and collaborate with teachers and administrators in schools with band 5 to 7 in certain academic and administrative aspects. By making SISC+ and SIP the monitoring requirements to schools with band 5 to 7 as an indicator, this study assumes that the schools in the band as a low-performing schools that require close attention by pedagogical practice and school administration experts. For the purposes of this study, nine out of the eleven schools in the low band were identified within the population.

\section{Research Methodology}

This study used survey method to collect data through questionnaire. All items have been tested for their validity and reliability. High-level thinking skills instruments were adapted from the Rosnani instrument (2014) and Rajendran's research instrument (2008); Rajendran's student centering activity (2008), teacher questioning from Rajendran (2008), Mayer et al. (2009), Braun et al. (2015) and Fisher (2007). Meanwhile, teacher modelling instruments were developed by this study through the process of strictness and reliability. Respondents are the students from Islamic Education of low-performing secondary schools in the rural area of Sabah (Kudat) and a total of 250 people were selected from a total population of 692 people using purposive and random sampling technique. This study used the Statistical Package for Social Studies (SPSS) version 22 to test its hypotheses.

\section{Findings}

\section{Differences in Student Centering Activity based on Race}

Based on analysis of One Way ANOVA test, there was no significant difference in the mean score for participation of student centering activity based on race $(F(4,251)=2.081 ; p=.084>$ $0.05)$. The mean score for the Dusun students was highest $(M=4.348, S$. $P=.424)$ while the mean score for Bajau students was $(M=4.004, S . P=.340)$. The mean score of students in Ubian was $(M=3.922, S . P=.491)$. The mean score for Kegayan students was $(M=3.970, S$. $P=.382)$. The mean score for the other students recorded was the lowest $(M=3.845, S$. $P=$ 
.211). Furthermore, there was no significant difference in the mean score of family income. Hence, the null hypothesis (Ho) stating that 'there is no significant difference in the variable of student-centering activities based on race' failed to be rejected.

Table 1: Analysis of One Way ANOVA for Difference in Student Centering Activity based on Race

\begin{tabular}{|c|c|c|c|c|c|c|c|}
\hline Variables & & Race & $\mathrm{N}$ & Min & SP & F Value & P (sig) \\
\hline Student & Centring & Dusun & 8 & 4.3482 & .42419 & 2.081 & .084 \\
\hline \multirow[t]{4}{*}{ Activities } & & Bajau & 38 & 4.0038 & .34032 & & \\
\hline & & Ubian & 158 & 3.9227 & .49071 & & \\
\hline & & Kegayan & 40 & 3.9696 & .38206 & & \\
\hline & & Others & 12 & 3.8452 & .21065 & & \\
\hline
\end{tabular}

*significant level at .05

\section{Differences in Teacher Questioning based on Race}

Based on analysis of One Way ANOVA, there were significant differences in the mean score of teachers' questioning variable based on the race of students $(F(4,251)=3.209 ; p=.014$ $<0.05)$. The mean score for the Dusun students was the highest $(M=4.365, S . P=.596)$. The mean score of Bajau descent students $(M=4.059, S . P=.294)$. Furthermore, the mean score of Ubian students was $(M=3.934, S . P=.522)$. The mean score of Kegayan students was the lowest $(M=3.823, S . P=.311)$. The mean score of students from other races was $(M=3.833$, $\mathrm{S}$. $\mathrm{P}=.050)$. The mean score for family income was significantly different. Hence, the null hypothesis $(\mathrm{Ho})$ stating that 'there is no significant difference in the variable of teacher questioning based on race' was rejected. The following table is a summary of One Way ANOVA test to evaluate this hypothesis.

Table 2: Analysis of One Way ANOVA for Difference in Teacher Questioning based on Race

\begin{tabular}{lllllll}
\hline Variables & Race & $\mathrm{N}$ & Min & SP & F Value & P (sig) \\
\hline Teacher Questioning & Dusun & 8 & 4.3646 & .59585 & 3.209 & .014 \\
& Bajau & 38 & 4.0592 & .29441 & & \\
& Ubian & 158 & 3.9335 & .52171 & & \\
& Kegayan & 40 & 3.8229 & .31077 & & \\
& Others & 12 & 3.8333 & .05025 & & \\
\hline
\end{tabular}

*significant level at .05

\section{Differences in Teacher Modelling based on Race}

Based on analysis of One Way ANOVA, there were significant differences in mean score of teacher modelling variable based on race of students $(F(4,251)=3.015 ; p=.019<0.05)$. The mean score for the Dusun students was seen the highest $(M=4.406, S . P=.376)$. The mean score of Bajau descent students was $(M=4.192, S . P=.359)$. Furthermore, the mean score of Ubian students was $(M=4.032, S . P=.476)$. The mean score of Kegayan students was $(M=$ $4.138, \mathrm{~S} . \mathrm{P}=.333)$. The mean score of students from other races was seen as the lowest $(M=$ 3.901 , S. $\mathrm{P}=.212$ ). The mean score was observed to be significantly different. Thus, the null hypothesis $(\mathrm{Ho})$ stating that 'there is no significant difference in the teacher modelling based 
on race' was rejected. The following table displays a summary of One Way ANOVA test to evaluate this hypothesis.

Table 3: Analysis of One Way ANOVA for Difference in Teacher Modelling based on Race

\begin{tabular}{lllllll}
\hline Variables & Race & N & Min & SP & F Value & P (sig) \\
\hline Teacher Modelling & Dusun & 8 & 4.4063 & .37649 & 3.015 & .019 \\
& Bajau & 38 & 4.1924 & .35900 & & \\
& Ubian & 158 & 4.0316 & .47587 & & \\
& Kegayan & 40 & 4.1375 & .33259 & & \\
& Lain-lain & 12 & 3.9010 & .21230 & & \\
\hline
\end{tabular}

*significant level at .05

\section{Difference in High Level Thinking Skills based on Race}

Based on analysis of One Way ANOVA, it was found that there were no significant differences in the mean score of high level thinking skills variable based on race of students $(F(4,251)=$ 1.989; $p=.097>0.05)$. The mean score for the Dusun students was the highest $(M=4.142, S$. $P=.284)$. Mean score of Bajau descent students was $(M=4.042, S . P=.351)$. Meanwhile, the mean score of Ubian students was $(M=3.908, S . P=.367)$. The mean score of Kegayan students was $(M=3.907, S . P=.279)$. The mean score of students from other races was the lowest $(M=3.889, S . P=.278)$. Family income mean score was seen with no significant difference. Hence, the null hypothesis (Ho1) stating that 'there is no significant difference in the KBAT variable based on race' failed to be rejected. The following table summarises One Way ANOVA test to measure this hypothesis.

Table 4: Analysis of One Way ANOVA for Difference in KBAT based on Race

\begin{tabular}{|c|c|c|c|c|c|c|c|}
\hline Variables & & Race & $\mathrm{N}$ & Min & SP & F Value & $\mathrm{P}$ (sig) \\
\hline Kemahiran & Berfikir & Dusun & 8 & 4.1417 & .28382 & 1.989 & .097 \\
\hline \multirow[t]{4}{*}{ Aras Tinggi } & & Bajau & 38 & 4.0421 & .35052 & & \\
\hline & & Ubian & 158 & 3.9076 & .36652 & & \\
\hline & & Kegayan & 40 & 3.9067 & .27911 & & \\
\hline & & Lain-lain & 12 & 3.8889 & .27756 & & \\
\hline
\end{tabular}

*significant level at .05

\section{Discussion}

The results of this study clearly showed that students from every ethnicity were equally involved in the student centring activities implemented by teachers in the teaching and learning at school. In addition, the same situation occurred for high-level thinking skills. The results showed that students from every race had a level of thinking skills that did not differ significantly between one and another. Both findings proved that from the aspect of ancestry, the students have the space to freely cooperate with one another without the dominance of any particular race. Looking from a far more perspective than race and ancestry, this is likely to happen as students are familiar with friends from the same district since elementary school. In terms of social activity and thinking skills, students were found to move across racist 
gaps and made the background of the socio-economic system as equality. Hence, as the same majority group, there is no problem to socialise among them in activities organised by teachers outside the classroom as evidenced in the Kanazawa study (2010). Similar to Goleman's (2006) view, students also have a different thinking trait as they are in a large group of people and share equality from another angle regardless of ancestry. These social and environmental factors influenced students' thinking style either positively or negatively. Therefore, teachers require space and opportunity to be part of the 'society' of the students to bring more positive influences to the students.

Despite similarities, this study also explained the differences between each race towards the teacher questioning in the classroom. Dusun students showed more sensitivity and participation in the questionnaire with teachers in the classroom, while students from the Kegayan showed the least interest and participation in the study population. Dusun students were seen more familiar with teacher modelling than Bajau, Ubian, Kegayan and others. The attitude of the Dusun students to the questioning and modelling explains their interest in understanding Islam. As stated above the previous survey (Hanafi, 2012), most of the Dusun people still believe in and practice ancestral practices especially in terms of animism. This was evidenced by the lively celebration of rituals during certain times including the harvest season. So, this study gives additional input that the dilemma between beliefs (animism) and religions (Islam) is likely to cause the Dusun students to stand out for questionnaire. This was positive from the context of student development from the Dusun community. However, from the larger context as rural students, other races of students should be encouraged to participate in the questionnaire and understand the teachers' profound explanation as they are still lagging behind the urban students (Suhaimi, 2014). In addition, rural students have the tendency to be more aggressive in school (Tamuri, Mahmud \& Bari, 2005) and require more spiritual guidance from teachers rather than physical punishment approaches. The previous surveys (Suhaimi, 2014; Tamuri, Mahmud \& Bari, 2005) reinforced the findings of this study so that every race should be presented to the teacher's dialogic equally, while the Dusun spirituality can be given more emphasis without leaving other races. Teachers should always take note of the age of adolescents who are constantly exposed to misunderstandings in the aspects of $a^{\prime}$ qìdah, i'badah, morals and other issues of furu'.

\section{Conclusion}

The four variables studied can be divided into two; the variables that received great influence from society and those receiving influence from the learning at school. The variables of student centring activity and thinking skills received more influence from social activities of students with communities outside the school. Teacher questioning and modelling were observed more applicable only in the classroom. Therefore, it is worth noting that every student from all races showed the same commitment, ability and tendency in the variables of student centring activities and thinking skills. It is just 'resuming' social activities with outside friends into classes with context as students. This was similar with a way of thinking that receives great influence from outside the school community. In contrast to the activities emphasised during school hours including questioning and modelling, only the minority Islamic students showed more interest. Among the lessons learned from this scenario are the strength of external community's influence on social and student-thinking styles in line with Goleman's (2006); Nachiappan et al., (2018); Hussaini, Bakar, Yusuf, (2018) 
survey. This scenario demands teachers to be part of the great influence of students in appropriate ways. In addition, Islamic minority students clearly require deep religious knowledge to avoid confusion between the Islamic religion and the beliefs that were previously held. Finally, Muslim students who feel that their knowledge in Islam is adequate should be given more attention because it is likely to be a mere assumption, whereas in terms of practical and daily practice, there is still much to be learned as the knowledge of Allah is so vast. The discussion of this study was not necessarily aimed at the attention of the community and the teachers in the study population alone. For a population outside the study, the Dusun student learning scenario may match the atmosphere of learning of Islamic minority students in the outer population of Kudat and can be applied to the muallaf students. Teaching and learning in schools is a da'wah process that must be implemented in full wisdom, attracting and able to give huge impact to produce Muslims and believers who are useful for the religion of Islam, society and nation.

\section{References}

Ainon \& Abdullah, H. (2005). Pemikiran Reka Cipta: Kaedah Mengajar dan Bahan Latihan Untuk Guru dan Jurulatih. Pahang: PTS Publications and Distributions Sdn Bhd.

Bahagian Pembangunan Kurikulum. (2016). Dokumen Standard Kurikulum dan Pentaksiran Pendidikan Islam. Putrajaya: Kementerian Pendidikan.

Bono, D. E. (2000). Six Thinking Hats. London: Penguin Books.

Bono, D. E. (2015). Serious Creativity: How to Be Creative under Pressure and Turn Ideas into Action. New: York: Random House.

Braun, J. D., Strunk, D. R., Sasso, K. E., \& Cooper, A. A. (2015). Therapist use of Socratic questioning predicts session- to-session symptom change in cognitive therapy for depression. Behaviour research and therapy, 70, 32-37.

Brookfield, S. (2005). The power of critical theory for adult learning and teaching. The Adult Learner, 85.

Coombs, P. (2009). Mengajar Secara Efektif. (Terjemahan: Siti Aishah Mohd Elias). Kuala Lumpur: Institut Terjemahan Negara Malaysia.

Ellen, R. L. (2014). The Power of Creative Thinking. Kuala Lumpur: YLP Publication.

Fisher, R. (2007). Dialogic teaching: Developing thinking and metacognition through philosophical discussion. Early Child Development and Care, 177(6-7), 615-631.

Fisher, R. (2009). Creative Dialogue: Talk for Thinking in the Classroom. New York: Routledge.

Hanafi, H. (2012). Worldview Dan Amalan: Pengalaman Kadazan Dataran Penampang Sabah. Borneo Research Journal, University of Malaya, 1(1).

Howard, K., \& Nancy, C. (2006). Logic and Contemporary Rhetoric: The Use of Reason in Everyday Life. Australia: Thomson Wadsworth.

Hussaini, U., Bakar, A.A., Yusuf, M.-B., O. (2018). The Effect of Fraud Risk Management, Risk Culture, on the Performance of Nigerian Banking Sector: Preliminary Analysis, International Journal of Academic Research inAccounting, Finance and Management Sciences 8 (3): 224-237

Jeffrey, B., \& Woods, P. (2009). Creative Learning in the Primary School. New York: Routledge. Jonathan, S. (2011). Remaja Kreatif Luar Biasa. Selangor: Millenia.

Kamarul, A. J., \& Ab Halim, T. (2007). Pendidikan Islam: Kaedah Pengajaran dan Pembelajaran. Johor: Universiti Teknologi Malaysia. 
Kanazawa, S., \& Norman, L. (2015). Happiness In Modern Society: Why Intelligence And Ethnic Composition Matter. Journal of Research in Personality, 59(4), 111-120.

Krathwohl, D. R., \& Anderson, L. W. (2009). A taxonomy for learning, teaching, and assessing: A revision of Bloom's taxonomy of educational objectives. Longman.

Marton, F., \& Saljo, R. (2005). Approaches to learning In F. Marton, D. Hounsell \& NJ Entwistle. The experience of learning: implications for teaching and studying in higher education. 3rd (Internet) edition.

Mayer, R. E., Stull, A., Deleeuw, K., Almeroth, K., Bimber, B., Chun, D., \& Zhang, H. (2009). Clickers in college classrooms: Fostering learning with questioning methods in large lecture classes. Contemporary Educational Psychology, 34(1), 51-57.

Mel, S. (2010). Pembelajaran Aktif: 101 Strategi Untuk Mengajar Apa Jua Subjek. (Terjemahan: Zainab Ahmad). Kuala Lumpur: Institut Terjemahan Negara Malaysia.

Nachiappan, S., Hock, K. E., Zabit, M. N. M., Sukri, N. A., Suffian, S., \& Sehgar, S. C. (2018). The Analysis of Career Choice Factors and Ways to Address Unemployment Problems among Youths at the Perak State Youth Council. International Journal of Academic Research in Progressive Education and Development, 7(3), 14-25.

Noor, H. (2011). Pengajaran dan pembelajaran: penelitian semula konsep-konsep asas menurut perspektif gagasan Islamisasi ilmu moden.

Nur, A. (2016). Discussion on Religion among Students. World Engineering, Science and Technology Congress 2016 (Estcon 2016), 23.

Osler, A. (2010). Students' Perspectives on Schooling. Open University Press. McGraw Hill.

Rahim, A. R. (2001). Nilai-Nilai Murni Dalam Pendidikan: Menghadapi Perubahan dan Cabaran Alaf Baru. Kuala Lumpur: Utusan Publications and Distributions.

Rajendran, N. (2008). Teaching Higher Order Thinking Skills in Language Classrooms: The Need for Transformation of Teaching Practice. Unpublished. Doctoral Dissertation. Michigan State University, East Lansing. USA.

Rajendran. (2013). Teaching and Acquiring Higher Order Thinking Skills: Theory and Practice. Tanjung Malim: Penerbit Universiti Pendidikan Sultan Idris.

Richard, P., \& Linda, E. (2006). Critical Thinking: Learn the Tools the Best Thinkers Use. Ohio: Pearson Prentice Hall.

Robert, F. (2009). Creative Dialogue: Talk for Thinking in the Classroom. New York: Routledge.

Rohani, A., \& Nordin, A. R. (2010). Hubungan Guru-Pelajar dan Kaitannya Dengan Komitmen Belajar Pelajar: Adakah Guru Berkualiti Menghasilkan Perbezaan? Jurnal Pendidikan Malaysia, 35(2), 61-69.

Rosnaini, S., Maimun, A., \& Mok, S. S. (2011). Siri Kemahiran Generik: Kemahiran Berfikir. Selangor: Penerbitan Multimedia Sdn Bhd.

Rosnani, H. (2003). Malaysian Teachers' Attitudes, Competency and Practices in the Teaching of Thinking. Intellectual Discourse, 11(1).

Rosnani, H. (2012). Memenuhi Aspirasi Kemahiran Berfikir Dalam Pelan Pembangunan Pendidikan Malaysia 2013-2025 Menerusi Inkuiri dan Pedagogi Filosofiyyah Dalam Kalangan Guru. Persidangan Majlis Dekan Fakulti Pendidikan, Universiti Teknologi Malaysia.

Seman, S. (2005). Interaksi Lisan Dalam Pengajaran dan Pembelajaran Komponen Kesusasteraan Melayu (Komsas) dalam Mata Pelajaran Bahasa Melayu.Tesis Doktor Falsafah. Fakulti Pendidikan, Universiti Kebangsaan Malaysia, Bangi. 
Stephen R. C. (2013). The Seven Habits of Highly Effective People. United Kingdom: Simon \& Schuster UK Limited.

Suhaimi, T. (2011). Gaya Pertautan Dan Motivasi Pelajar, Serta Pengajaran dan Bimbingan Guru Pendidikan Islam Terhadap Pembelajaran Terarah Kendiri (PTK) Pelajar. Tesis PhD. Universiti Malaysia Sabah.

Swartz, R. J., Fischer, S. D., \& Parks, S. (1998). Infusing the Teaching of Critical and Creative Thinking into Secondary Science: A Lesson Design Handbook. Critical Thinking Books and Software, PO Box 448, Pacific Grove, CA 93950-0448.

Tamuri, A. H., Mahmud, Z., \& Bari, S. (2005). Permasalahan pelajar-pelajar fakir miskin di daerah Sabak Bernam. Jurnal Pendidikan, 30, 21-33.

Tamuri, A. H., Yusop, A., Osman, K., Awaluddin, S., Rahim, Z. A., \& Razak, K. A. (2004). Keberkesanan P\&P Pendidikan Islam ke Atas Pembangunan Diri Pelajar. Laporan Penyelidikan Fakulti Pendidikan, UKM dan Jabatan Pendidikan Islam dan Moral (JAPIM), KPM.

Tegin, J., Ekvall, S., Kragic, D., Wikander, J., \& Iliev, B. (2009). Based Learning and Control for Automatic Grasping. Intelligent Service Robotics, 2(1), 23-30.

Waheedawati, W. (2003). Penggunaan Penyoalan Lisan Dalam Kalangan Guru Sejarah di Sekitar Bandar Sibu. Kertas Projek Sarjana Pendidikan. Fakulti Pendidikan, Universiti Kebangsaan Malaysia, Bangi. 